\title{
Democracy, Citizenship and Local Press: The Case of the USA “Local Press in Boulder"*
}

\author{
Fatma Gürses \\ Department of Journalism, University of Kastamonu, Kastamonu, Turkey \\ Email: fatosgurses@gmail.com, fgurses@kastamonu.edu.tr
}

Received 22 February 2015; accepted 20 March 2015; published 23 March 2015

Copyright (C) 2015 by author and Scientific Research Publishing Inc.

This work is licensed under the Creative Commons Attribution International License (CC BY). http://creativecommons.org/licenses/by/4.0/

(c) (i) Open Access

\begin{abstract}
Nowadays, democracy discussions including a variety of different approaches are made due to the impact of globalization. In this respect, local press comes to the fore as a significant element in the development of participatory citizenship and democracy values from the periphery to the center in a way to reflect differences. This research aims at examining the relationship amongst democracy, citizenship and local press using the local media Boulder, a city in Colorado state of the USA, as a case study. The study is composed of two parts. In the first part, we are going to discuss theoretical frameworks that will help us to better understand the concept of democracy and citizenship, the impact and importance of participatory citizenship on democracy and democratization. The second part includes the historical development of Boulder city and Colorado state. Their sociological and economic features in order to understand the local background of the geography in which the newspaper we examine in our case study are located. The significance of local media and press in Boulder for the state in general and its historical development are analyzed also including examples including the flow of information rendering the participation of citizens possible. In this respect, the importance of local press for the participation of citizens and its impact on democratization are examined.
\end{abstract}

\section{Keywords}

Citizenship, Democracy, Local Press, United States of America, Boulder Daily Camera

\section{Introduction}

Democracy has operated throughout history via direct democracy in the Ancient Greece as citizens' governing themselves or representative democracy with the advent of nation-states via citizens' being governed by elected representatives. Nation-state has claimed that citizens bound through the citizenship status under the roof of a

*https://kastamonu.academia.edu/fatmagürses 
nation are free through representative democracy.

Until the First World War, nation was considered as a tool to protect what is really human in people, i.e. their autonomy represented by "equality and freedom" values. Democracy of this time defends freedom more than equality, contrary to today's democracies. With the advent of the industrial society, although this model amends, its very nature remains unchanged. It indeed takes the most mature form it has ever expressed itself through industrial democracy and welfare state. This social model resulted in the "West" to enjoy inner development and hegemony over the world for centuries (Touraine, 2005: 34-38). According to Huntington, (1996) global democratization has historically developed in "three waves.” The first, long wave (1828-1926) corresponds to Britain, France and the USA's taking basic rights and freedoms under constitutional guarantee via general and equal right to vote; the second (1943-1962) to Germany, India, Israel and Japan's adopting democracy, while the third wave to Greece, Portugal and Spain as well as Latin American countries as Mexico, Chile and some old Eastern Bloc countries' adopting democracy (as cited Gürcüoğlu, 2007: 30). The thesis of Huntington indicates that democracy advanced through these three waves with the advent of nation-states. In this respect, nation-state has used democracy as a means to unite its citizens around common values within the liberal system.

The fact that liberal democracy is established on "common principles and values" is based on the assumption that a pluralist society is found by citizens. Liberal democracy assumes the existence of citizens enjoying certain rights and liberties as subjects of social relations. The concept of citizenship melting down individual differences and thusly creating certain "sameness" normalizes the contradictions of liberal democracy and contributes to both individualization of social relations and their integration through the category of citizenship. Nation pointing to homogeneity ignores demands of the individual struggling to form its own identity within the existing diversity. This results in a legitimacy crisis in the liberal democracy implemented by the nation-state. The main reason for this legitimacy crisis is that the concept citizen based on "sameness" excludes difference (Keyman, 1997:291) Nevertheless, although nation-state attempts to overcome this crisis via democracy, citizens have developed dynamics to limit the sphere belonging to the state.

Hence, modern democracy is born out of individual's demand for freedom acting as an economic agent in the society and the power to assure freedom of humans. Again a second intellectual tradition narrowed the scope of state intervention via citizens' active participation in public affairs without suggesting any limitations to state power (Schnapper, 1995: 101). The status of citizens in liberal approach is determined according to subjective rights towards the state and other citizens. Subjective rights are negative rights of right holders enhancing the right to choose freely from outside pressure. Political rights provide citizens of the state to realize their special interests via voting. All citizens as citizens of the state can thus monitor whether state administration abides by social interests. Disintegration between state mechanism and the society cannot be overcome according to liberal approach, but it can be resolved through a democratic process (Habermas, 2005: 152-159). In this context, liberal democracy is regarded as a conciliative attempt. Normative gaps in the establishment of a balance between power and interest shall be covered by the concept of law state.

Limiting democracy through state might transform it. This is an element complicating the applicability of democracy which requires a pluralist understanding. The concept of "we" established by the nation-state via the bond of citizenship provides the basis for belonging to a nation and excludes the ones outside us." When we define "us" and "others" not ideologically ${ }^{2}$ but anthropologically based on cultural data, "others" become objects of knowledge, not political rivals for "us." In that case, the conflict between identity and difference might be overcome. According to liberal approach, the function of democratic process is to program the state according to the interests of the society. The basic commitment of a liberal democracy is the freedom and equality of its citizens as individuals. Liberal democracy was partially developed as a reaction to feudalism that defines political

\footnotetext{
${ }^{1}$ Stanton (2007), in this study regarding the definition of the West attempts to answer the question, "How to be Western" and then poses the question of the journal Economist asking whether Turkey can establish a legal framework paving the way for its EU membership. Another question is, do we need a certain "language" to be Western? This is not the case for French, English, and Italian etc. Is the culture then? "Stanton states that this cannot be the binding value, neither "economy" nor "democracy" can be this common feature because many other countries are now ruled by democracy. Why cannot we imagine countries like Taiwan, South Korea etc. as a part of the Western world? Our response to this question is "freedom of press." Freedom of press might not be necessary for the democracies of respective countries, but it is indispensable to be "Western." Free press seems to be the only criterion to be "Western." Freedom of press enhanced public discussions and the promoting of thought. Stanton states that countries like Turkey have had many reforms, but public discussions and feedback was missing." (Stanton, 2007: 46-47).

${ }^{2}$ Ideology is a contradictory term. Herman and Chomsky used this term to understand what is going on in the world. They consider it as a Marxist term. Anti-communist ideology was for instance used by the US media discourse. However, overall media discourse is obviously related to economy. (Muhlmann, 2010).
} 
rights and economic opportunities of individuals based on the group they pertain to (Kymlicka, 1998: 71) Therefore, individual is defined as citizens of the state having equal rights with others not based on the group or segment s/he pertains to.

Hence, three necessary conditions of every democracy are as follows: restriction of power, representation of political governors and citizenship (Touraine, 2005: 333). Citizenship as a political status and equality of citizens require a democratic administration (Heater, 2007: 208-212) Citizenship has always been considered as an indicator of elitism in almost all phases of history. Rousseau, one of the Enlightenment thinkers, emphasizes that citizens shall be more or less close to one another in terms of knowledge and welfare for the democracy to operate healthily. If some are very knowledgeable and others are completely ignorant, if some are rich enough to buy many citizens and others are poor enough to sell themselves, which democracy cannot function in a healthy manner (Akşin, 1996: 27). Hence, democratic society includes balance in income distribution and relations between individuals and the society; the socialization of a citizen is inescapably related to democratic socialization and the role of citizenship.

According to an interactive structural perspective for a democratic society, the role of a citizen legally defined so as to include equality based on certain minimum standards is envisaged. Contrary to participatory democracy, representative democracy defines the "good citizen" within the scope of regional, socio-economic and ethnic differences. In line with the interactive perspective, citizenship is not rigidly defined and structured but it is rather non-formal, developed in an interpersonal context based on subjective choices and voluntarism (Iclihov, 1990: 12-13). In other words, a citizenship definition including democratic dynamics within the perspective of participatory citizenship is envisaged.

The critics towards this approach are based on the fact that although the individual has certain gain through basic rights and citizenship consciousness with the phenomenon of globalization, it does not have much chance to implement these rights practically within daily life. Especially nation-states witness important contradictions and complications in this matter. It is indeed difficult and prone to conflicts and challenges to both abide by the changes and conditions imposed by IMF, World Bank and the global capital and sustain social integrity, solidarity and institutions required by nation-states (Gürcüoğlu, 2007: 25). In this respect, press is an important feature that has enhanced the participation of citizens and the functionality of democracy since the foundation of the nation-states. Therefore, local press is the unique instrument enhancing these democratic values to expand from periphery to the center. Relationship between local press and democracy remains its significance despite all adverse dynamics of globalization.

Within the scope of the above perspective, this study aims at examining the experience of the creation of citizens in the participatory democracy via local press with respect to the historical development of local press in Boulder city of Colorado, USA. The main purpose of the research is to examine the importance of local press in the foundation and advance of democratic values based on the case study in Boulder. Our research is composed of two parts. Firstly, we explained the relationship between democracy and citizenship as well as local administration and local press. Secondly, historical development, sociological, economic features, the foundation of local media and press, their importance for the estate and the information flow enhancing the participation of citizens are examined via a historical development line of Boulder city, Colorado. In this respect, the role of local press in the participation of citizens and democratization is evaluated. The study is important in the sense that it is the first investigation at local level on the democratic struggle in the USA being, in contrast to Europe witnessing the birth of nation-states, a newly founded country based on multi-culturalism. Hence, it aspires to be a model for other similar studies.

\section{The Relationship between Democracy, Citizenship and Local Press: From Periphery to Center}

The thought that democracy will enhance a wider range of freedom and welfare, gave way to the concept of "participatory citizenship" including arguments going beyond the right to vote, a basic democratic right of citizens. Participatory citizenship is rendered possible through the political socialization of citizens ${ }^{3}$. Political socialization is based on strengthening democracy in the orientation of citizens. Therefore, it goes hand in hand with

\footnotetext{
${ }^{3}$ In their recent study on determining the agenda in political socialization, Kiousis, McDevitt and Wu (2005) state that political tendencies of adolescents were shaped within ideological devotion and partisan identities, but such factors had less influence on their choices (Kiousis \& McDevitt, 2008: 482-483).
} 
democracy, democratic citizenship and democratic participation of citizens to administration (Iclihov, 1990: 1). Hence, political socialization is established and developed via information gathered at schools, in the family and via communication tools.

Many studies reveal the fact that what is learned in the family and ideological identity of the family have important roles in the ideological harmonization of children. This model ignores identity formations or state that they are unrealistic defending that children's interest in news, their discussions with peers and family members were important cognitive functions in the inter-personal process. Schools are other important factors in such stimulations. Schools are indeed unique spaces where the state can incessantly convey its political message overcoming cultural and socio-economic obstacles. Schools enhance a level of social interaction unparalleled to that of home (Kiousis \& McDevitt, 2008: 483). Another factor as important as family and school in political socialization is information enhanced by mass communication channels. Macro and micro organization of the state has a role in this information type. Information flow enhanced by local administrations, as micro-level institutions, to mass communication tools provides the participation of citizens as knowing subjects.

Hence, the participation of citizens, the principle of pluralism and responsibility to be accountable to electors are minimum requirements of democratic local administrations. Participation of citizens to local administrations enhances problems to be more healthily determined and solutions to be more effective and consistent. Democracy, in today's world, is not only representative but includes the participation of citizens to solution processes regarding their issues. In this respect, democracy envisages local communities' freely governing themselves in issues closely related to themselves via democratic means and methods. Therefore, the functionality and sustainability of democracy is possible through wider participation of people. The modern management understanding envisages people's participation in the decision-making procedures regarding streets, parks, squares, infrastructure, cultural and social life, technology, economy and history of a city. The identity of a city is further developed, sustained and settled through technological, economic, social structure and activities, as well as the democratic culture of citizens. Democratic processes play a significant role in the formation of economic, political, social and cultural spheres (Gürcüoğlu, 2007: 44-46). Hence, the relationship between local administrations and the local press is important in the functionality of these democratic processes.

There are various approaches in journalism with respect to press' freedom and transfer of information to citizens. Citizenship journalism ${ }^{4}$, the significance of alternative press and local press are among these issues. "Alternative Media Theory" being a part of these discussions is based on certain common grounds at various levels between wider national and social movements in global arena and small groups in micro and macro conjectures. This approach orients towards alternative media movements at macro levels. Traditionally, alternative media theories are classified in two groups. The first group defines alternative media in macro social perspective and aims at struggling with mainstream media in hearts and minds of citizens. It adopts a counter-hegemonic approach in social project. Alternative media sets targets for itself via small groups and communities and adopts certain practices accordingly. It has a role in the representation of women, workers and young people. The second type of theories examines impacts of alternative media broadcasting in daily life (Fontes, 2010:382). Local and alternative media acting as areas to enhance the participation of wider and more variable people provides participatory democracy to develop.

Alternative press was born in the USA at the beginning of $1960 \mathrm{~s}^{5}$. Hippi groups and journalists against Vietnam War started to publish cheap newspapers with different contends and styles at the end of 1960s and beginning of 70s in the USA. These newspaper as alternative means against traditional commercial journalism had a local impact. They had similar characteristics to national press until the mid-70s. In 1980s, titles and circulation gained significance as main income channels (Franklin \& Murphy, 1991: 25, 84-85). In fact, this was not limited to alternative press. Generally, the main income of the press in the USA in 1970s was advertisements. As to local media, it was basically local companies (Sim, 1969: 50). Ironically, local press employees and newspapers are similarly more intertwined with local business circles nowadays. In times of internet, news and editorial models have changed ${ }^{6}$ (Anderson, 2013: 166). This created local media institutions having direct ties with the

\footnotetext{
${ }^{4}$ American press has been separating journalism for people and journalism for citizens for the last 20 years. Anglo-American studies are generally on freedom of speech, cultural-political issues and information and communication (Muhlmann, 2010: 6).

${ }^{5}$ Being a geographically large country changes the structure of news broadcasting in radio, newspapers and press in general. Canada broadcasts to the country in five regions, the USA to four. Canada has strongly used broadcasting system being partially public in the formation of a nation (Aldridge, 2007: 23).

${ }^{6}$ Nowadays, a higher organization established through the union of differ rent organizations and a news media come to forefront. Complex institutions like World Trade Center and International Monetary Fund have adopted to this model (Stanton, 2007: 11, 179-189).
} 
market. In other words, in terms of Serge Halimi, the follower of Noam Chomsky in France, "market journalism" is highly common.

We might mention two incompatible opinions regarding local press. The first claims that local press has come to be related to wider investment and thusly national press chains within the scope of monopolization and that it became a part of this chain in local level. Second is related to the change in local press with regard to new technologies (Franklin \& Murphy, 1991: 21). Another problem with respect to local journalism practices unique to the USA is that laws change from one state to another. A situation regarded to violate "the confidentiality" of citizens in a state can be considered as legal in yet another state. It is the same with respect to categories as liars, gamblers etc. Hence, different decisions can be taken in similar cases. In that case, the case is appealed to a higher court. For instance, in a similar case in the USA, a decision was taken in a lawsuit claiming that newspapers do not violate private life as citizens are not public or official figures. In that case, questions as, "Who is a public figure," "Who is an official figure," "Is it possible to separate them from private life" come to mind (Berry, 1976: 21-22). Thus, such different applications affect local and national publishing policies of newspapers.

The news includes transfer of an event within an ideological process and situation. Western countries and the USA more easily acquire popular images when compared to East. Citizens of countries like India, Brazil etc. cannot easily travel to West, for instance. These countries acquire news concerning European Union, legal ameliorations, US defense politics and the World Bank via "Western" mass communication channels that do not belong to them (Stanton, 2007: 32). Another example claiming that the news is ideologically constituted is that the news itself is a fiction-imagination. For instance, terrorist attacks in North America, Indonesia or Spain, earthquake in Japan, flood in South America are recreated, "fictionalized" through terms of local actors from the other edge of the world. For CNN, Israel-Lebanon War in the Middle East can be a "fiction," but this event is "painful" for a US citizen living there (Stanton, 2007: 2-3). That's why local elements of news-making are important in the expansion of democratic values from the periphery to the center.

One of the main elements and perhaps the most important one in the creation of a democratic culture is freedom of expression and press. In places where the citizens gradually become desperate, timid and ignorant against political power, the government somehow ignores this to sustain its political power, the dependency/independency of the media, one way or another benefiting from this government, becomes problematic, democratization and the culture of democracy is complicated; democratic sustainability is either retarded or deliberately halted. Citizens in democratic societies have two information sources. First are information and documents pertaining to administration and the second are information and documents attained through mass communication channels (Gürcüoğlu, 2007: 126-127). The second is only attainable through freedom of expression and press. Therefore, freedom of expression and press are indispensable elements of democracy and participatory citizenship.

Local press contributes to the propagation and settlement of the culture of democracy in local level. According to Vural (1999), local newspapers being the oldest and most significant tools of local communication are key tools for mass communication. These newspapers sometimes regulate the daily lives of people and therefore published to inform the public, but they also have the power to influence opinion and mold public opinion. They have a more important position than other mass communication channels with their power to regulate local people. In an ever shrinking world where borders are being eliminated, society and individuals within that society, on one hand, experience the feeling of being a citizen of the world through news coming from around the world via hundreds of channels and on the other hand, approaches to its close surrounding, culture and community via sentiments of devotion and solidarity. At this point, local press becomes the most important reference guide of individuals. Press is the biggest socialization tool for the local culture. Local newspapers are the most significant utilization, sharing and communication tools in the social life of the area (as cited Gürcüoğlu, 2007: 16).

A strong democracy can only be attained through efficient and participatory citizens who are not mere spectators, but consider politics as a way of life. Local press contributes propagation and settlement of democracy culture in local level. Local people are in need of information concerning what is going on in the town, social, political, cultural and economic developments. People are more concerned about developments in their close surroundings rather than events at the national level. The biggest task of local press is to adequately and suffi-

\footnotetext{
${ }^{7}$ Serge Halimi from France being a follower of Noam Chomsky defined in 1997 the columnists of Le Monde Diplomatique as "the new watchdogs" of the new order. He states that they economically and politically act as the watchdogs of the system. He defines the journalism of Bob Woodward and Carl Bernstein in Watergate scandal as “watchdog journalism” (Muhlmann, 2010: 13).
} 
ciently inform people concerning the problems in the city and enhancing the follow-up of initiatives taken to solve these problems (Atabek, n.d.: 47-49). Therefore, it provides the necessary democratic environment for participatory citizenship.

Every political system creates political ideas appropriate to the membership of their young citizens. Therefore, training of citizens has been applied since the ancient times. Political education and learning are still central today. Today in US culture, children meet with the flag of their country at early ages. Patriarchal myths regarding the founders of the USA shape the "American lifestyle." Similar to tribal bonds, large communities encourage young members to know these myths; interiorize them via wide range of applications and a political harmony is thus attempted to be created. In this respect, citizenship attempted to be shaped in the USA is based on the perspective to sustain the functionality and sustainability of the state through a "homogeneous" society. Although this is a pessimistic outlook, it is witnessed that such an approach is adopted in cities and campuses of the USA. The first indicator of a certain alienation from this homogeneity is uprisings stemming from the distress caused by goods produced by the system. Second is the rejecting stance of the black population. Uprisings sustained by black Americans have had wide support. Political scientists orient towards groups at a larger dimension, including Mexican-Americans, indigenous people, and poor whites (Greenberg, 1970: 8-12). Hence, local press is an important factor in the US having a wide geographical territory in the advance of democratic values from the periphery to the center.

\section{Local Press in Colorado and Boulder}

Up to now, we tried to explain concepts as democracy, citizenship and local press in general. In the following part of our study, we will attempt to examine historical foundation and development of Boulder local press, alongside with its relations to other local elements in the country. In this respect, we are going to dwell on the sociological, historical and economic structure of the local region. Then, we are going to take a look at the foundation of the local press, its influence and status in the region the means it adopts to make use of democratic elements.

\subsection{Short History of Colorado State}

Colorado located at the mid-west of the USA corresponds to the geographical area including the highest peak of the country Elbert Mountain. The state whose capital is Denver has a very cold climate. It is named after Colorado River, meaning red in Spanish. It is also known as the centennial state. Colorado having a wide indigenous population where the first settlements date back to 13 thousand years is a state uniting different cultures. The first settlers were Apaches from the southwest of the state, Comanches from the northern Wyoming, Araphoe and Cheyennes from Minnesota having similar languages, indegenios tribes coming from Utes on the west living in Utah (Noel, 2011: 14, 21-24). Colorado having hosted different cultures includes Hispanics composed of Spanish people and Mexicans and Italians and the French to be called European-American. Spanish people came before English speaking communities from New Mexico and Rio Grande and settled in South Colorado, especially in San Luis Valley close to Santa Fe. It is a difficult region with a cold temperature and high altitude. A short while later, Anglo-Saxons settled in central and northern regions. Railway installed in 1870s changed the life in the valley and a new town called Alamosa was established. Colorado increased its population with the discovery of valuable mines. English speaking community, though coming later, belittled significant contributions and influence of Mexican Americans to the history of the state due to the political power they attained. However, Mexican Americans giving their name to the state had undeniable amount of contribution to the country. Many Mexican towns indeed disappeared by now. The Spanish names of these towns were changed to English. Until European-American settler arrived in 1850, civil war between Spanish people coming from New Mexico and indigenous people continued for 230 years (Noel, 2011: 67-77). Colorado received official state status in 1876 (Runnells, 1976: 6).

Colorado whose population reached 1.670,000 in 1957 with the economic advance through agriculture, cattle and ovine farming has attracted the attention of thousands of tourists with its natural beauties, mountains and lakes. Gold and silver are main minerals, while lead and zinc are other significant minerals. The state having a coal yard is the most significant region producing molybdenum. It also has uranium and wide oil reserves. Although it is a relatively small state, it has six state universities and colleges. Moreover, the state also has United State Air Force Academia and other higher education institutions (Kobre, 1959: 248). 
Life has changed in Colorado after the Second World War with television, wide highways enhancing transportation with other states, water projects, advancing economy and air transportation. Denver started to accommodate federal agents in Denver Federal Center and the city was called, "the second national capital." (Ubbelohde, Benson, \& Smith, 2006: 333-334). The capital of Colorado Denver had 35 thousand of population in 1880, while today this number reached 133 thousand at the beginning of the century and 415 thousand later on. It almost doubled its population in 1958 to 700 thousand as a metropolitan city. Denver is the business and financial center of Rocky Mountain region. Apart from being a cultural center, it is an important city also in education. It has important airports, railroads and highways for the USA and the world (Kobre, 1959: 248). Boulder-Denver Turnpike was opened in 1952 between Boulder and Denver. 13,774 people passed through this highway until 1966 by paying 25 cents. It has the Office of National Standards (now called the Institute of National Standard and Technology) and National Air Research Center. The saying "workers in Colorado are 'happy campers' imply that people in the region do not have problems in finding jobs and they are economically comfortable. Nevertheless, according to latest reports (2003), $17 \%$ of workers are not "satisfied with their job." This ratio is $22 \%$ in general in the USA. Workers are paid very poorly and have stated their discomfort due to poor salaries and not being able to work in good and desirable positions (Ubbelohde et al., 2006: 333-348, 400-401). Colorado, preserving its natural beauty at Central America, has witnessed lively journalism activities throughout its history.

\subsection{Boulder: Athens of Colorado State}

Boulder, being one of the most developed cities of the state, is located around 1 mile away from Arkansas River at the $40^{\text {th }}$ latitude and $38^{\text {th }}$ longitude (Abbott, Leonard, \& McComb, 1994: 477). Being at the hillsides of Rocky mountains having 1655 meters of altitude, Boulder is situated at the northwest of Colorado's capital Denver, 40 $\mathrm{km}$ away from it. Hills known as Flatiron are symbols of the city. Boulder Creek (river) flows at the west of the city. Boulder is the best business and career center of the USA. It has bicycle paths, pedestrian paths and connections. It mostly has liberal democratic electors. It is the most crowded eleventh city of Colorado State (Boulder, Colorado, USA, n.d.). Accommodating many companies, Boulder is connected to other parts of the state through railroads and highways. Boulder is governed by a city council and nine council members are elected amongst well-educated residents (Runnells, 1976: 31).

Boulder was founded at the end of the $19^{\text {th }}$ century. 15 miners from Nebrasca camped in Boulder Canyon known as "Red Rocks." The leader of the group Captain Thomas Aikins agreed with Niwot Arapahoes and settled down in the region (Runnells, 1976: 5, Ubbelohde, Benson, \& Smith, 2006: 60). The discovery of gold in 15 January 1859 caused new settlements to emerge in the region. Areas at the north of Boulder River (creek) were separated into 56 shareholder in 10 February 1859 for 1000 dollars each and 4044 dollars in total (Center for Colorado \& The West, n.d.). Gregory Gulch ${ }^{8}$ organized the first mining camp in 8 June 1859 (Abbott et al., 1994: 56). The first school of Colorado was established in 1860 and the first church in 1872, both in Boulder. The first high school of Colorado started giving education in 1876 again in Boulder. Commercial centers were established in 1877 and a university was established under the initiative of residents (Runnells, 1976: 5).

Education is important for Boulder. In 7 November 1861, the mayor William Gilpin officially allowed the establishment of the first big university of the state, namely the University of Colorado Boulder ${ }^{9}$. Nevertheless, it was only 15 years later due to the adverse conditions caused by the war that the old building now located in Colorado University campus was established in 20 September 1857. Within the same year, it became the first higher education institution of the state. The foundation of the university was completed in 1876 through a budget of 15,000 dollars from the state parliament with the efforts of the mayor Charles F. Holly and 45,000 dollars allocated from the residents. It was officially opened in 2 September 1877 with a faculty composed of 44 students under the administration of Dr. Joseph A. Sewall. With the participation of 12 new employees to the staff in 1878, the university started to give regular education (Runnells, 1976: 67-68; Center for Colorado \& The West, n.d.). At the end of the $19^{\text {th }}$ century, Boulder became self-sufficient in education (Pettem, 2010: 39). Nowadays, The University of Colorado Boulder is a public university with 46,000 students, while the private Naropa University adopting Buddhist principles has 1000 students. Despite having started to give education as a small university, the University of Colorado rapidly developed. Boulder County News published an advertise-

\footnotetext{
${ }^{8}$ John Gregory was the first to discover gold in Colorado known as “Greogory’s Gulch” (Western Mining History, n.d.).

${ }^{9}$ University of Coloroda Boulder ranked 97 in 2013-2014. (The World University Rankings, n.d.).
} 
ment of the university under the title, "coming together in a nice society, nice houses and a nice university." Denver Republican, on the other hand, published an advertisement of the university in 1882 under the title, "almost a Western University with few awards and a great assertion” (Abbott et al., 1994: 126). Cincinati (Ohio), Lexington (Kentucky), Nashville (Tennessee), Ann Arbor (Michigan), Faribault (Minnesota), Berkeley (California) are the biggest cities of their respective states. In 1880s, Boulder was also known to be "the Athens of the Western World” as the most developed city of its state (Pettem, 2010: 41).

With the advance of railroad transfer in Boulder in 1873, the number of settler substantially grew. The population grew from 300 to 3000 within a couple of years. Many buildings were established via briquettes made up of wood and slime. In 1871 the first bank, in 1874 the first national bank and again in 1874 the first water system was established. Texas-Colorado Chautauqua ${ }^{10}$ was founded in 1898 to serve as the recreation center for Texas residents. Smallpox epidemic in 1880 was the biggest disaster of the city, while a great flood occurred in 1894. Many people in 1893 lost their jobs due to the economic crisis. Boulder people with a great cultural and historical heritage having first established their library in 1906 were involved in commerce and farming. The population was six thousand in 1900 and 11 thousand in 1910. The real population boom occurred after the Second World War. The timberland including Araphoe glaciers was purchased in 1929. Therefore, Boulder became the second city of the USA deriving water from glaciers. A program including the support of the federal government was implemented in 1930s during the times of economic tremor (Runnells, 1976: 6-7). The foundation of the highway connected Denver to Boulder in 1950 and its launch in 1952 are among the historical events of the advance of Colorado (Abbott et al., 1994: 334). Until 1966, daily 13774 people used this railroad paying 25 cents (Ubbelohde et al., 2006: 348). It became a settlement for hippies in 1960s. At the beginning, the democrats had the highest votes in Colorado (Abbott et al., 1994, 76, 334). Nowadays, on the other hand, it is one of the most well-known liberal democrat cities. In April 2012 elections, 69.5\% voted for democrats, $28 \%$ for republicans, 1.5\% for liberal party (The Denver Post, 2012 Elections Colorado, n.d.).

\subsection{Local Press in Boulder}

Boulder is the media center of the northern Colorado. Boulder whose population increased and economy boosted with the incoming students has significant functions in the incorporation of citizens in local administration via local press. The local press has broadcasts aiming at informing residents so as to contribute to the participation of Boulder citizens in decision regarding problems of the city.

Denver Post a weekly newspaper published in Denver is one of the newspapers making local news. Boulder Magazine published three times a year was founded in 1978. Boulder having TV stations in the market has many radio receivers in Forth Collins and Denver. It is the center of Soldier of Fortune magazine and Paladin Press found in 1970. Apart from The Daily Camera, Boulder County Business Report published two times a month, Boulder County Kids and 50 plus Marketplace News are among the local publications of Boulder (CityData.com: Cities of the United Satates: The West, n.d.). Rocky Mountain News still being the most important newspaper of Colorado is amongst the mostly sold newspapers of Boulder. The competition with Denver Post was finalized in 2001 with a Joint Operating Agreement (JOA). In 26 February 2005, the journalist Joyn Temple used to say, "Two offices are still in fight as if their lives depended on it" (Vaughn, 2008: 455).

Local press in Colorado state (see. Appendix 1) was born in the second half of the $19^{\text {th }}$ century coinciding with the foundation of the state. The oldest newspaper of the state Rocky Mountain News was founded by William Byers in April 1859. The Colorado Daily published five times a week was first founded in 1892 for CU-Boulder as a campus newspaper (Colorado Online Historical Newspapers, n.d.; Boulder County Colorado GenWeb, 2011). Similarly, local press in Boulder coincides with the foundation of the city. The Daily Camera is the mostly read local newspaper.

\subsubsection{The Daily Camera}

Daily Camera was launched in 17 March 1891 as "one of the unique newspapers of the USA if not of the world.”

\footnotetext{
${ }^{10}$ Chautauqua was a program as an adult education movement in the USA becoming popular especially at the end of $19^{\text {th }}$ century and beginning of $20^{\text {th }}$ century. Named after Chautauqua Desert, the program has raised important musicians and speakers. Chautauqua has become a successful education movement. Chautauquas, had religious functions in many states giving summer school training. At the end of 1919 it also gave training on political issues of the time as the rights of child workers and women movement. Chautauqua education movement was especially efficient in rural parts of the state. With the advance and development of mass communication channels, its impact was gradually declined (Chautauqua Trail, n.d.).
} 
In April 1892, Bert Ball sold the newspaper to Boulder Publishing Co. established by L. C. Paddock and Valantine Butsch (Center for Colorado \& The West, n.d.) (see Figure 1). From 1892 to 1940, L.C. Paddock was the editor of Boulder Camera (see Figure 2) ${ }^{11}$. Having a highly expensive infrastructure with high-speed stamping and linotype machines, Camera attracted attention in Colorado press with its advertisements and sales success. Revolutionary printing inspired all newspapers in Denver (Ubbelohde et al., 2006: 237). L.C. Paddock started to use the slogan "science is the lamp of life" for its newspaper (Pettem, 2010: 40).

The newspaper having at first been published weekly started to be printed nightly in 1893. Paddock became a name in not only Boulder but the state and overall journalism world. The newspaper was sold in 1 July 1931 to a printer from Kansas Oscar Stauffer. However, this printer failed to become successful and Paddock returned to the newspaper and continued its publishing life in 1931 under the name Boulder Daily Camera. When Paddock was deceased in 10 July 1940, his son Alva Adams Paddock started his career in Camera that would last for 52 years (Center for Colorado \& The West, n.d.).

After the Second World War, Camera was awarded with one of the most prestigious awards of the USA, F.W. Ayer typographical printing in 13 March 1947 among around 10.000 US newspapers. When Alva Adams Paddock deceased in 7 November 1961, his wife Annie Laurie became the president of Boulder Press and managed the newspaper from February 1960 to June 1992 for 32 years. Ridder Publishing became one of the partners of the newspaper in April 1969 and Lu Monroe and Norm Christiansen became members of the executive board. In 1970s, Camera started its career under an a lot less known name, Daily Camera Extra. Monroe retired in Marc1970 and Christiansen in 1976. The successful editor J. Edward Murray 1976-1982, Janet Chusmir 19821987, John L. Dotson, Jr. 1987-1992 and Harold Higgins 1992-1995, Barrie Hartman 1995-2007, Scripps (19972009) were the following editors of the newspaper (Center for Colorado \& The West, n.d.).

Camera has been prepared in the same building in Pearl Street 11 since its foundation. This building was then renovated into a two-floored house (see Figure 3). A new publishing room was annexed in 1973. In 2008, a new building was annexed in Walnut Street. The newspaper was moved to 5450 Western Avenue in 20 August 2010 (Snider, 2011).

\subsubsection{News Samples from Boulder Local Press}

At the beginning of the $20^{\text {th }}$ century, Colorado residents witnessed historical journalism practices of American press history through information from the local press. These years coincided with the peak of tabloid newspapers. Important events were conveyed to people through attractive titles. One of them was on the great influenza epidemic erupted after the First World War (1918). Newspaper frequently published news about this deadly disease known as Spanish flu spread to Boulder, Colorado Springs, Pueblo and Denver. Rocky Mountain News used intriguing titles as "more fruits and vegetables," "Elect republicans, eradicate the fear of flu." Schools and churched were closed to public and various measures were taken. From September 1918 to January 1919, around 8 thousand people lost their lives (Abbott et al., 1994: 268).

Another event was in the limelight of the local press. Concerning the rise of Bolsheviks to power in Russia and Hungary, Rocky Mountain said, "Bolshevik administration found having involved in the worker strike in Seattle." Thousands of strikes erupted in the state. Many Colorado residents were exhausted and angry. Denver Post, used headlines supporting the federal government as "Bolsheviks and anarchists destroying the state take their lesson.” Colorado administrators were targeting people by saying that having red flags meant being communist saying that such demonstrations would not be tolerated for the security of the state. In October 1919, a law was issued with the suggestion of mayor Oliver Shoup to repress anarchism envisaging over 20 years of jail sentence, a series of detentions by General Mitchel Palmer known as "Palmer raids" followed the law. ${ }^{12 \text { " } 4}$ thousand communists are arrested in 33 cities including 249 activists. Denver city council penalized the freedom of speech. Speeches that might evoke uprisings were penalized. Only 8 activists were arrested before 2 January 1920, while this number substantially increased after the coming into effect of the law. The news covering the events in Denver Catholic Register, Denver Post and Rocky Mountain News were censured. They joined forces with the federal government to break the strikes of politicians and organized radical demonstrations supporting them (Abbott et al., 1994: 268-269).

\footnotetext{
${ }^{11}$ The founder of Daily Camera Lucius Carver Paddock (10 August 1859-31 July 1940) was the editor-in-chief of the newspaper for the last 49 years. His son Alva Adams Paddock (1867-1961) worked in the same post office for 21 years (Runnells, 1976: 5; Lucius Carver Paddock n.d.).

${ }^{12}$ Palmer raids is a term coined to describe the detentions of radical leftist militant at the end of 1919 and the beginning of 1920. Detentions under the rule of General Mitchell Palmer caused great reactions and revolts (Spartacus Educational, n.d.).
} 


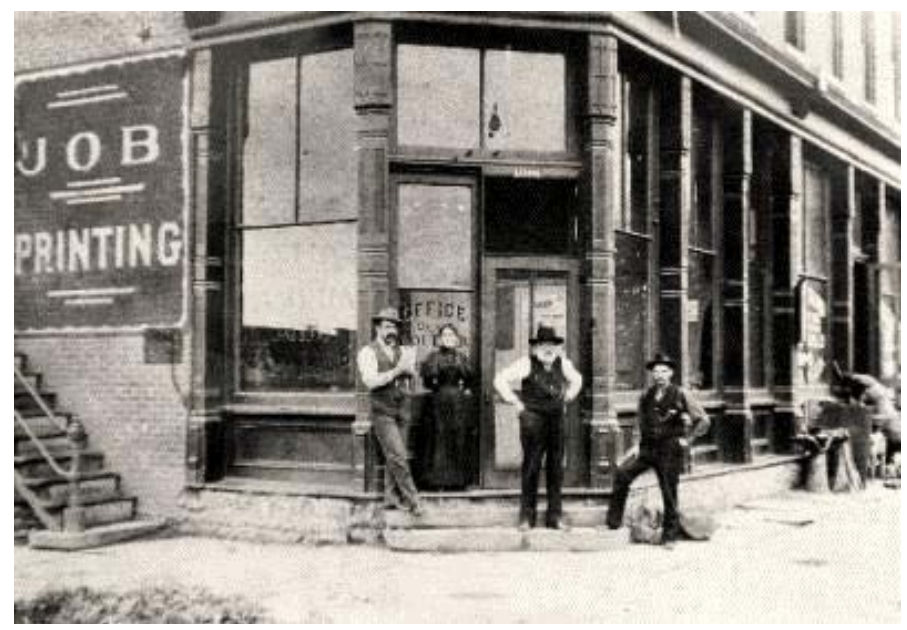

Figure 1. From left, Camera staff members Charles Butsch, Fannie Snell and Valentine Butsch stand in front of the newspaper s building around 1892. The name of the fourth person is not known. The Camera began operations in downtown Boulder on March 17, 1891 (Snider, 2011).

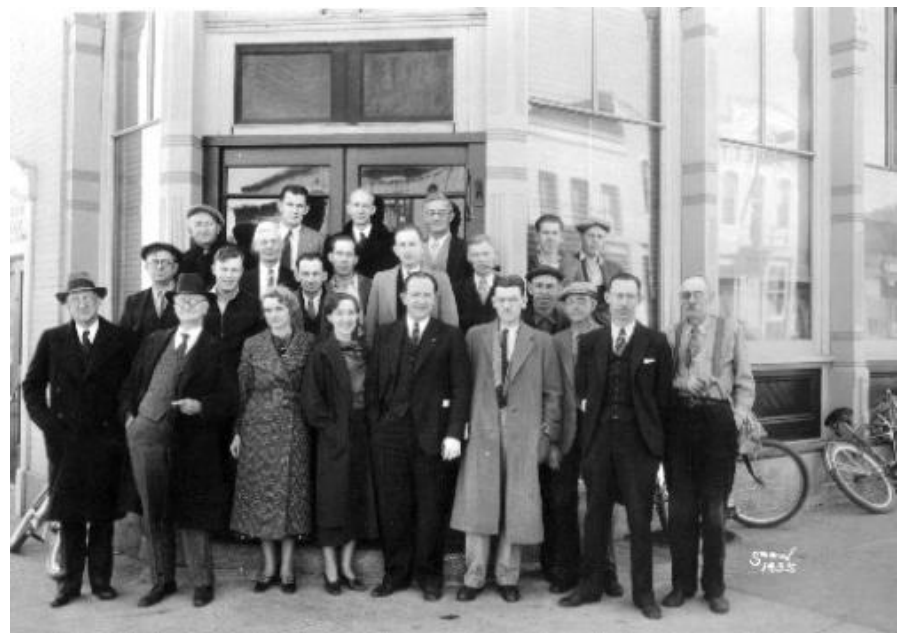

Figure 2. Camera staff members, including longtime editors A. A. Paddock and L. C. Paddock, stand in front of their downtown building in 1935 (Snider, 2011).

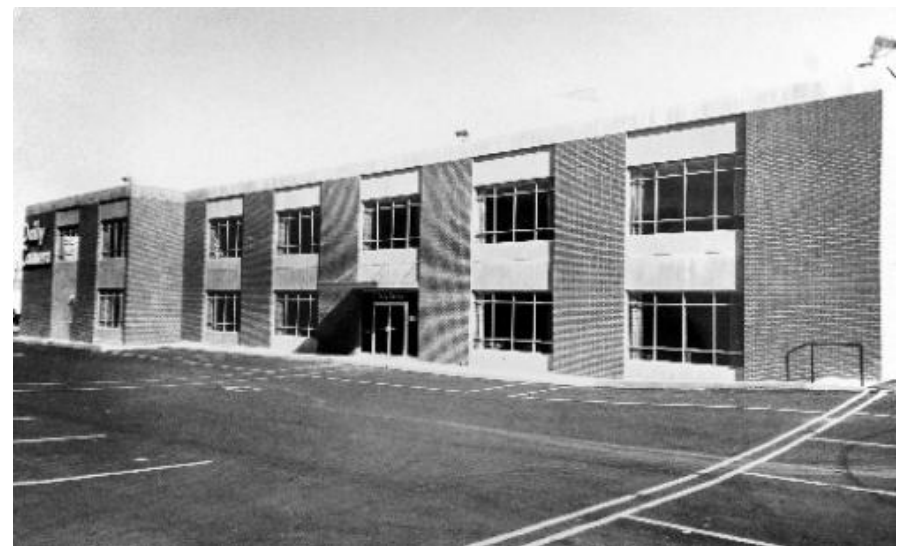

Figure 3. After years of remodels and additions, the historic building at $11^{\text {th }}$ and Pearl streets was demolished and replaced by this new building with two floors and a basement in 1963. That structure remains as the eastern part of the present Camera headquarters. (Snider, 2011). 
Boulder local press was highly efficient in informing the residents with news also covered by the national press. Events with national repercussions were also covered by the local press, while local news enhances the flow of information from periphery to the center. Global events were included in the agenda of the local press; national political news was presented to citizens with titles suitable to broadcasting policies of the local press.

\section{Conclusion}

Nowadays, democracy discussions including a variety of different approaches are made due to the impact of globalization. Participatory democracy may be the first of them, though radical democracy seems to be more convenient for the estimates of globalization. In this respect, press created by nation-state ideology is an important element in our times to enhance democracy since the $19^{\text {th }}$ century. While the press has been shaped in Europe, the center of nation-state ideology, under the influence of such dynamics, local press has had an important role in the USA having a multi-cultural society being established via different dynamics in settling and sustaining democratic values. Participatory citizenship is one of the basic elements of today's globalization with respect to democracy and democratization. The press needs to have information to enhance citizens' participation in the administration and use of democratic means. National and global presses are not sufficient to bridge this gap. Therefore, information means of local press shall cover this gap and enhance the development of a participatory citizenship and democracy from the periphery to the center.

Boulder local press situated in mid-Colorado state we examined in our study had a role in the establishment of such democratic values. It had a significant role in establishing institutions and system of a newly found country, informing people and enhancing their participation. Local press has had a noteworthy influence in the establishment of a country via then materially non-existent institutions, creating a regime assuring the unity of various nations in this country, integrating them under the roof of a nation-state. Boulder created its own local press to create this multi-cultural structure with its diverse ethnic features, natural beauties and welfare. Examining the impact of local press on the participation of citizens' to decision-making processes via news analyses and spectator analysis in this multi-cultural structure will be complementary to the research. The study envisages being a model for other researches on local press, democracy and citizenship.

\section{References}

Abbott, C., Leonard, S. J., \& McComb, D. (1994). Colorado, A History Of The Centennial State. Niwot, CO: University Press of Colorado.

Akşin, S. (1996). Uluslaşma Sürecinde Devlet ve Yurttaş (State and Citizens in the Nation-Building Process). In Çileli, M.,

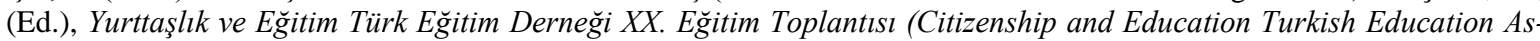
sociation XX. Education Meeting) (pp. 23-45). Ankara: Türk Eğitim Derneği Eğitim Dizisi.

Aldridge, M. (2007). Understanding the Local Media. Maidenhead: Open University Press.

Anderson, C. W. (2013). Rebuliding the News: Metroplolitan Journalism in the Digital Age. Philadelphia: Temple University Press.

Atabek, N. (n.d.). Yerel Basin ve Yerel Demokrasi (Local News and Local Democracy). Journal of the Faculty of Communication, 47-54. http://www.journals.istanbul.edu.tr/iuifd/article/viewfile/1019012673/1019011901

Berry, T. E. (1976). Journalism in America: An Introduction to the News Media. New York, NY: Hastings House.

Boulder, Colorado, USA. (n.d.). About Boulder. http://www.bouldercoloradousa.com/about-boulder/

Boulder County Colorado GenWeb. (2011). Boulder Newspapers: Dates, Founders, Publishers and Editors. http://theusgenweb.org/co/boulder/newsclips/boulder_newspapers.html

Center for Colorado \& The West. (n.d.). Boulder. https://coloradowest.auraria.edu/content/boulder

Chautauqua Trail. (n.d.). A North American Cultural Renaissance. http://www.chautauquatrail.com/faqs\#Frequently-Asked-Questions

City-Data.com: Cities of the United States: The West (n.d.). Boulder: Communications. http://www.city-data.com/us-cities/The-West/Boulder-Communications.html

Fontes, C. (2010). The Global Turn of the Alternative Media Movement. In K. Howley (Ed.), Understanding Community Media (pp. 381-390). Thousand Oaks, CA: SAGE Publication. http://dx.doi.org/10.4135/9781452275017.n33

Franklin, B., \& Murphy, D. (1991). What News? The Market, Politics, and the Local Press. London, New York: Routledge.

Greenberg, E. S. (1970). Consensus and Dissent: Trends in Political Socialization Research. In E. S. Greenberg (Ed.), Political Socialization (pp. 1-16). New York: Atherton Press. 
Gürcüoğlu, M. F. (2007). Demokratikleșme Sürecine Katkı Sağlayan Bir Araç olarak Yerel Basının, Yerel Yönetim Meclisleri Bağlamında Kamuoyunu Bilgilendirme Düzeyi: Eskişehir SAkarya ve İstikbal Gazeteleri Örnekleminde (Powered Contribution to the Democratization Process as a Tool Local Newspapers, Public Disclosure Level of Local Government Councils Context: The Future of Newspapers in Eskişehir Sakarya and Samples). Ph.D. Thesis, Eskişehir: Anadolu University, Institute of Social Sciences.

Habermas, J. (2005). Öteki Olmak, “Öteki”yle Yaşamak (Being the Other “Other” Is Meant to Live). İ. Aka, Trans., İstanbul: Yap1 Kredi Press.

Heater, D. (2007). Yurttaşlı̆̆ın Kısa Tarihi (A Brief History of Citizenship). M. Delikara, Trans., Ankara: İmge Press.

Iclihov, O. (1990). Dimensions and Role Patterns of Citizenship in Democracy. In O. Ichilov (Ed.), Political Socialization Citizenship Education and Democracy (pp. 11-25). New York: Teacher College Press.

Keyman, F. (1997). Globalleşme ve Türkiye: Radikal Demokrasi Olasılığı (Globalization and Turkey: Radical Democracy Chance). In N. Bilgin (Ed.), Cumhuriyet, Demokrasi ve Kimlik (Republic, Democracy and Identity) (pp. 281-294). İstanbul: Bağlam Press.

Kiousis, S., \& McDevitt, M. (2008). Agenda Setting in Civic Development Effects of Curricula and Issue Importance on Youth Voter Turnout. Communication Research, 35, 481-502. http://crx.sagepub.com http://dx.doi.org/10.1177/0093650208315978

Kobre, S. (1959). Modern American Journalism. Ph.D. Thesis, Tallahassee, FL: Tallahassee Institute of Media Research, Florida State University. http://hdl.handle.net/2027/uc1.b3555096

Kymlicka, W. (1998). Çokkültürlü Yurttaşlık (Multicultural Citizenship). A. Yılmaz, Trans., İstanbul: Ayrıntı Press.

Lucius Carver Paddock (n.d.). http://www.findagrave.com/cgi-bin/fg.cgi?page=gr\&GRid=11111050

Muhlmann, G. (2010). Journalism for Democracy. J. Birrell, Trans., Malden, MA: Cambridge.

Noel, T. J. (2011). Colorado: The Highest State. Boulder, CO: University Press of Colorado.

Pettem, S. (2010). A Sense of Time \& Place Revisited. Charleston, SC: Charleson History Press.

Runnells, D. D. (1976). Boulder: A Sight to Behold: Guidebook: Self Guided Tours of the Historic City, Geology and Scenery, University of Colorado, Plus Short Side Trips to Nearby Areas. Boulder, CO: Estey Printing Co.

Schnapper, D. (1995). Yurttaşlar Cemaati, Modern Ulus Fikrine Dair (Citizens Community, on the Modern Nation Intellectual). Ö. Okur, Trans., İstanbul: Kesit Press.

Sim, J. C. (1969). The Grass Roots Press: America’s Community Newspapers. Ames, IA: Iowa State University Press.

Snider, L. (2011). Daily Camera. http://www.dailycamera.com/boulder-county-news/ci_17106735

Spartacus Educational (n.d.). The Palmer Raids. http://spartacus-educational.com/USApalmerR.htm

Stanton, R. C. (2007). All News Is Local: The Failure of the Media to Reflect World Events in a Globalized Age. Jefferson, NC: McFarland \& Co.

The Denver Post, 2012 Elections Colorado (n.d.). Boulder County 2012 Elections Results. http://data.denverpost.com/election/results/county/boulder/2012/

The World University Rankings (n.d.). University of Colorado Boulder. http://www.timeshighereducation.co.uk/world-university-rankings/2014-15/world-ranking/institution/university-of-colora $\underline{\text { do-boulder }}$

Touraine, A. (2005). Birlikte Yaşayabilecek miyiz (Can We Live Together)? O. Kunal, Trans., İstanbul: Yapı Kredi Press.

Ubbelohde, C., Benson, M., \& Smith, D. A. (2006). A Colorado History. Portland, OR: West Wind Press.

Vaughn, S. (2008). Encyclopedia of American Journalism. New York: Routledge.

Western Mining History (n.d.). Central City, Colorado. http://www.westernmininghistory.com/towns/colorado/central-city/ 


\section{Appendix 1: The Publication in Boulder}

1) Valmont Bulletin, est. January 1, 1866-September 1868.

2) Boulder Valley News April 3, 1867-September 1868.

3) Boulder County Pioneer February 10-September 14, 1869.

4) Boulder County News October 12, 1869-November 8, 1878.

5) Boulder County News and Courier November 15, 1878-October 26, 1883.

6) Boulder News \& Banner Nov. 1883-June 5, 1888.

7) Boulder News June 12, 1888-November 1914. the paper June 1, 1914 and turned it into a morning daily: Boulder Morning News November 10, 1914-February 17, 1916, when it merged with the Herald.

8) Boulder County Bee April to November 1875. It is believed that the Bee was the result of a merger of the Boulder Eagle and Longmont Inter-Ocean, both of which ceased publication in April 1875.

9) Colorado Banner September 30, 1875-September 1883.

10) Boulder Herald February 18, 1880-1916. It was followed shortly by a sister daily:

Boulder Daily Herald April 17, 1880-February 14, 1916.

11) Boulder News-Herald February 18, 1916-February 29, 1932, daily. A weekly News-Herald was also issued. Arthur Parkhurst, known as a crusading editor, brought new life to the News-Herald.

12) Boulder Sentinel 1 July-September 1871. A Longmont Sentinel was published in the same period.

Boulder Sentinel 2 June 1884-November 29, 1890.

13) Boulder Miner 1888-1889. It was absorbed by Boulder Tribune October 18, 1889-September 21, 1921.

14) Boulder Camera September 27, 1890-1891, weekly, Frederick P. Johnson and Bert Ball, founders.

Daily Camera March 17, 1891 to present.

15) Boulder County Miner \#2 July 8, 1901-December 30, 1920.

Boulder County Miner \& Farmer 1920-June 1949. (In 1940 the Miner \& Farmer and the Journal combined their plants but issued separate papers.)

16) Boulder Sentinel \#3, April 4-18, 1946, only two issues.

17) Rocky Mountain Eagle September 17, 1873-April 18, 1875.

18) Home Mirror 1880, a literary monthly.

19) Colorado Representative June 10, 1897-December 12, 1903

Boulder Representative (The name was changed back to the original name in 1898.) The Representative espoused Free Coinage. Donald Oehlerts says it was continued as the Semi-Weekly Times.

20) Boulder Times, 1897-1907. The name was changed to Semi-Weekly Times February 17-September 29, 1903. It continued as Weekly Times or Times or Boulder County Times October 8, 1903-February 14, 1907.

21) Friday Social \& Industrial Review 1899, short lived.

22) Labor Leader 1900-1902.

23) Oil News 1901-1902, absorbed into the Camera.

24) Boulder Advertiser 1903-1904.

25) Saturday Truth 1903-1904.

26) Free American September-October 1904.

27) W.C.T.U.Messenger 1905-?,

28) Boulder Citizen May 27-April 4, 1909.

29) Coloradoan 1915-1918, a weekly magazine of comments with an occasional dash of condemnation.

30) Progressive Citizen March 23-April 17, 1917, daily.

31) Rocky Mountain American January 31-July 31, 1925; William Francis, ed. The paper was a voice for the Ku Klux Klan.

32) Boulder Free Press 1931, briefly.

33) Boulder Advertiser 2, April 15, 1932-November 1932.

34) The Remainder 1932.

35) Boulder County Journal September 22, 1932-September 29, 1933.

36) Journal October 3, 1933-April 20, 1944. In 1940, it merged its plant with the Miner \& Farmer, but the two papers were issued separately. It was revived as Boulder County Journal May 8, 1947-1952.

37) Wall Paper November 1932-1933.

38) Boulder Star November 24, 1932-January 19, 1934 semi-weekly. 
39) Broadcaster 1938-1939.

40) Boulder Mirror October 7, 1942-1944. It was begun as a theatre advertiser, known as the Skipper.

41) Trailerite 1948.

42) Boulder Forum June 23-October 15, 1950, Frank Swerer.

43) Boulder Reporter July 10-November 30, 1952.

44) Lens-Leader May 1954-?, D.H. Loving, founder. Merged into Lafayette Leader.

45) Downtown Shopper 1963-1979, begun as a monthly in 1963 but changed to a weekly about two years later, then to every other week. In 1966 the name was changed to Town \& Country, a weekly and discontinued spring 1979.

46) Boulder County Commercial Ledger . The June 11, 1970, issue is listed as Vol. 90 in Colorado Historical Society Records. It hasn't been found in other newspaper lists.

47) Express, 1970, Community Free School; underground press.

48) Boulder County Business Report January 1980 to present. It is a monthly.

49) Boulder County Courant September 24, 1983-?.

50) Boulder Courier 2, May 21, 1987.

51) Boulder Weekly August 1993-to present, "an alternative-style newspaper.

52) University of Colorado Newspapers.

53) Portfolio 1882-1892. The first University of Colorado publication was a four-page, magazine-sized paper issued quarterly.

54) Silver and Gold September 13, 1892-May 2, 1952.

55) Colorado Daily February 5, 1952 to present, though not an official university publication after 1971.

56) Working Press, later Campus Press, 1978-present. When the Press foundered in 1993, the Journalism and Mass Communications School suggested a joint venture with the Colorado Daily, with the Campus Press becoming an insert in the Daily.

57) Colorado Daily Sun dates unknown. Inter-Mountain Press said in 1922: Colorado Reporter, a second CU newspaper 1949 (Boulder County Colorado GenWeb, 2011). 